$1-1-2008$

\title{
Capitalism, identity politics, and queerness converge: LGBT employee resource groups.
}

Rod P. Githens

University of the Pacific, rgithens@pacific.edu

Follow this and additional works at: https://scholarlycommons.pacific.edu/ed-facpres

Part of the Education Commons

\section{Recommended Citation}

Githens, Rod P., "Capitalism, identity politics, and queerness converge: LGBT employee resource groups." (2008). Benerd School of Education Faculty Presentations. 278.

https://scholarlycommons.pacific.edu/ed-facpres/278 


\title{
Capitalism, Identity Politics, and Queerness Converge: LGBT Employee Resource Groups
}

\author{
Rod P. Githens
}

University of Illinois at Urbana-Champaign

Lesbian, gay, bisexual, and transgender (LGBT) employee resource groups have brought about substantial organizational change within corporations. Capitalist structures have enabled these changes to occur more quickly in the private sector than within the public sector. In this paper, I explore how capitalism has converged with two approaches of organizing around sexuality: identity politics and queerness. As a result of this convergence, human resource development has occurred at the individual, organizational, and societal levels.

Keywords: Diversity, Sexuality, Employee Resource Groups

Lesbian, gay, bisexual, and transgender (LGBT) employee groups provide social support/networking opportunities to workers and to provide a platform from which sexual minorities and others can work toward organizational development and change within their workplaces. These groups take multiple forms: formally organized, informally organized, recognized by the employing organization, and existing outside the employing organization (e.g., in unions) (Githens \& Aragon, 2007). The number of LGB groups in Fortune 1000 companies (i.e., the top 1000 publicly-traded U.S. companies, based on revenue) grew from two in 1980 to 69 in 1998 (Raeburn, 2004b). ${ }^{1}$ These groups, commonly called employee resource groups (ERGs), ${ }^{2}$ result in human resource development at the individual, organizational, and societal levels. On the individual level, development occurs for members within the groups as they live more integrated lives and learn to facilitate organizational change. For those outside the groups, development occurs as the groups' formal and informal awareness activities reach those throughout the workplace. On the organization level, change occurs as ERGs bring policy changes, changes in organizational culture, and ultimately improve employee-employer relations.

Within HRD, many voices have called for broadening the scope of the field to include societal issues and the development of more humane and ethical workplaces (e.g., Fenwick, 2005; Hatcher, 2006; O'Donnell, 2007). ERGs provide one such location for this type of development. However, ERGs balance their activist agendas with the need to contribute to the organization. Corporate motivation for supporting these efforts is not necessarily altruistic and is often enabled by the capitalistic goal of improving organizational effectiveness (Gedro, 2007). Influenced by approaches that focus both on LGBT-specific identities and broader conceptions of sexuality, known as queer theory, these employee groups have continued the long tradition of advancing LGBT issues through capitalist structures. Through a conceptual and historical discussion, I argue that these groups resulted from the unique convergence of capitalism and two sometimes-opposing social organizing strategies: queer politics and identity politics. Although these groups exist in various forms and in multiple types of organizations, I focus on formallyrecognized ERGs within for-profit corporations (for a discussion of other types of groups, see Githens \& Aragon, 2007). This paper's purpose is to explore the ways in which the productive tensions between capitalism, identity politics, and queerness have manifested themselves in LGBT ERGs and created structures and activities that result in development for individuals, organizations, and societies.

The creation of the concept of homosexuality in the $19^{\text {th }}$ century resulted in a new pathological condition to label those who have sex with people of the same gender. Shortly thereafter, the formation of formal and informal groups based on this sexual identity was a subversive effort to exert power and shift a negative attribute into a powerful collective force by taking advantage of this pathological identity (D'Emilio \& Freedman, 1997; Foucault, 1978). As I explain later, the evolution of capitalism has provided the structures through which this unique identity has emerged (D'Emilio, 1993). These forces have resulted in numerous advances in the acceptance of LGBT individuals in society. However, some have argued that LGBT identity politics has reached its limits and that LGBT

\footnotetext{
${ }^{1}$ As of July 2007, the Human Rights Campaign database (www.hrc.org) lists 143 employee groups in Fortune 1000 companies.

${ }^{2}$ The groups are also commonly called "affinity groups” or “employee networks.'

Copyright (C) 2008 Rod P. Githens
}

In (2008) T. J. Chermack (Ed.), Academy of Human Resource Development Conference Proceedings. Bowling Green, OH: AHRD. 
individuals should argue for individual liberties rather than equality as a minority group (e.g., Yoshino, 2006). Others advocate queer and universalizing approaches (rather than identity-based approaches) in which sexuality is seen as fluid and existing on a continuum (Sedgwick, 1990). They argue that such approaches are more appropriate because of the opportunity for opening productive discussions by examining the normalization of heterosexuality. Much LGBT activist work has aimed for civil rights protections or focused on homophobia as a psychological condition to be cured (Britzman, 1995). Broader queer approaches have the potential to open up conversations and include a wider range of individuals. However, the adoption of more complex queer approaches has implications for how sexuality is addressed in workplace settings. Instead of seeking to create an understanding of and recognition of LGBT persons, queer approaches by employee activists would seek to complicate sexuality and gender by dealing with the multifaceted approaches to "performing" gender and sexuality. I also consider the warnings of those who contend that radical deconstruction in queer theory leads to a loss of grounding that can result in immobilization due to the rejection of sexual identity as a meaningful category (e.g., Green, 2002) I explore the practical ramifications of taking such an approach and the problems surrounding the normalization of queerness by corporations.

Throughout the paper, I integrate the literature from LGBT ERGs, employee activism, LGBT studies, and queer studies to argue that these groups are products of complex interactions in which workplace activism occurs through capitalist structures, identity politics, and queer approaches to sexuality. My continuous reflection on the role of capitalism helps to ground the argument in the multifaceted demands faced by employee activists. The conceptual exploration of these issues, influenced by social science and cultural studies approaches, contributes to our understanding of how employee groups lead to development of individuals, organizations, and societies.

\section{Capitalism and the Rise of LGBT Employee Activism}

D'Emilio (1993) argues that the rise in gay and lesbian identity in the U.S. is a direct result of the structures created by capitalism. He explains that homosexual acts and tendencies have occurred throughout history; however, the idea of being gay or homosexual is a relatively new phenomenon (also see Foucault, 1978). D'Emilio concludes that the emergence of such identities was a slow process that started in the colonial era when capitalism began replacing the widespread system of individual household production. Over decades, the number of self-sufficient households declined. These households had relied on the nuclear family (i.e., husband, wife, children) for production, but became part of a system of wage labor that deemphasized self-sufficiency. With household production, individuals needed to move into heterosexual relationships because of the central role that procreation played in living a sustainable life. Capitalism, on the other hand, allowed for selling one's labor and purchasing goods that were produced outside of the family. This shift resulted in a steady, gradual decline in household production and a decline in the importance of procreative relationships in maintaining a decent life (as evidenced by declining birthrates). As a result, individuals with same-sex attractions were no longer compelled to enter oppositesex relationships. Over the span of decades, people with same-sex attractions slowly started entering same-sex relationships and developing social networks that included others who also had same-sex attractions.

D'Emilio (1993) explains that this gradual change and the slow emergence of gay identities culminated in World War II, which resulted in the explosion of gay identity formation. The war took thousands of men and women from around the country and placed them into same-sex environments, in addition to placing those who already identified as gay into those environments. Same-sex sexual relations occurred throughout the war and many gays and lesbians remained in large cities after the war ended, which resulted in the formation of urban communities based on sexuality. Later, the Stonewall riots occurred (in 1969), which is seen as the formal beginning of the gay and lesbian liberation movement. However, D'Emilio explains that the structures of capitalism allowed the gay and lesbian movement to form a grassroots network that was activated after the events in 1969. In the last 30 years, this network was responsible for the pressuring of corporate leaders that resulted in astounding success in changing workplace policies.

Most post-World War II capitalists did not embrace gays and lesbians. In fact, there is a well-documented history of oppression by employers, especially during and after the McCarthy era (D'Emilio \& Freedman, 1997). After Stonewall, activists began targeting prominent companies like AT\&T, who were openly discriminatory in their hiring practices toward gays and lesbians (Raeburn, 2004a). The first LGBT ERG formed in 1978 (Raeburn, 2004a); however, it took years of work on the part of activists before most companies started adopting nondiscriminatory policies. Interestingly, corporations have been more progressive in their practices toward LGBT individuals than governmental agencies (for a discussion of federal government employment practices during the Clinton administration, see Hirsch, 2000). Many companies adopted LGBT-friendly policies before state and local 
nondiscrimination laws were changed to include sexual orientation. ${ }^{3}$ Most companies do not adopt these policies for purely altruistic reasons. One reason for adopting inclusive policies is to capture a larger share of what is perceived as a lucrative LGBT consumer market. ${ }^{4}$ By adopting these LGBT-friendly policies, companies often alienate other customers, particularly religious fundamentalists (for an excellent discussion of the complicated history of LGBT relations at Disney, see Truesdell, 2001). Many companies are willing to confront this risk. However, I argue that one of the most important reasons companies have adopted these policies is due to pressure by employee activists and to keep LGBT employees happy.

It is important to examine the conditions that created an environment where employers sought to ensure the satisfaction of LGBT workers, while risking the loss of customers. As capitalism created the structures for the creation of gay and lesbian identities, newer forms of capitalism have also created conditions in which a substantial portion of an individual's identity is wrapped up in work (Ciulla, 2000). In the 1950s, workplaces sought to improve productivity through enhancing human relations at work and implementing paternalistic employment practices (e.g., comprehensive pension programs, career-long employment). In the current era, these paternalistic practices have been replaced by new practices that are designed to increase worker productivity through helping employees create meaning through their jobs (Ciulla, 2000). Today, individual identity is intertwined with work, especially for many white-collar workers. As a result of this shift, work is no longer a place individuals go to sell their labor; instead, individuals go to work to seek meaning in their lives. With this identification of the workplace as a center of personal identity, it has become essential that employers keep their workers happy in order for workers to have meaningful careers (which leads to maximizing productivity). For a few decades, workers and employers assumed that most people would spend an entire career with one organization. Currently, most jobs are not secure and workers expect to have free choice in employment-moving from job-to-job in order to find the most meaningful and well-paying position. Workers are no longer consumers only after work hours when shopping for goods and services. They are now consumers at work. For example, workers now expect to find an ideal job and they are not afraid to leave an employer to seek a better deal elsewhere. With the replacement of defined-benefit pension plans by 401(k) plans, workers have little incentive to remain with an employer if they are not happy. Those who advocate free choice and autonomy celebrate this consumer mentality in employment. Later, I will return to a discussion of the dangers of this consumer mentality. On the upside, this consumerism in employment has allowed LGBT employee activists to encourage change in workplaces. In contrast, politicians and government administrators have not been as eager to adopt these suggested changes (neither in government employment practices nor in employment laws).

Over the last 35 years, LGBT activists have had major wins. However, the pace of change has been somewhat slow, especially in changing public policy. For example, only thirteen states and the District of Columbia (D.C.) prohibit discrimination in employment based on sexual orientation and gender identity and seven more prohibit discrimination based on sexual orientation (National Gay and Lesbian Task Force, 2007). Ten additional states prohibit this type of discrimination in public sector employment only. Although governments have been slow to recognize that LGBT individuals should be able to work without discrimination, policies in large corporations have changed much more quickly. Ninety-six percent of companies listed in the Fortune 100 prohibit discrimination based on sexual orientation, while only $51 \%$ of states and D.C. prohibit discrimination in state government employment (Human Rights Campaign Foundation, 2007). A more tangible measure of private sector support is seen through offering benefits to same-sex partners of employees, which $79 \%$ of Fortune 100 companies provide, compared to $27 \%$ of states and D.C. It is important to understand how the policies have changed so quickly in corporate America.

As explained above, capitalism has created structures that allowed homosexuals to create gay and lesbian identities and move toward equality with heterosexuals. However, corporate policies were not changed merely by the market's invisible hand. Contrary to corporate executives' perceptions that LGBT-friendly policies were the result of market forces, Raeburn's (2004b) evidence suggests strongly that employee activism played a major role in these changes. Employee activists working through ERGs and other means have brought this employee relations issue to the attention of management within corporations throughout the country. Due to the current iteration of

\footnotetext{
${ }^{3}$ At this time of this paper's publishing, U.S. federal laws do not prohibit employment discrimination based on sexual orientation or gender identity.

${ }^{4}$ As LGBT people have been viewed as lucrative consumer markets, some have feared admitting the reality that LGBT people are poorer, on average. According to Robson (1997), the false notion of the "affluent gay" has allowed anti-LGBT activists to refute notions of LGBT discrimination by claiming that they are rich and undeserving of protections. Robson draws parallels between the rhetoric about rich gay people and the pre-World War II anti-Jewish portrayals.
} 
U.S. capitalism, in which employees are expected to seek meaning through work, employee activists have been remarkably successful in their pursuit of changing corporate policies. This collective effort was made possible largely through the use of identity politics.

\section{Identity Politics and Queerness}

Identity politics is "a wide range of political activity and theorizing founded in the shared experiences of injustice of members of certain social groups" (Heyes, 2002, para. 1). The classic debate over identity politics is familiar to many social and ethnic movements and is especially well known within LGBT circles. The debate centers around whether members of a socially constructed group choose to adopt a fixed identity in order to gain political power or whether they reject the fixed identity because of the limiting nature of defined identities (Gamson, 1995). For LGBT people, much of the social change that has occurred can be credited to the adoption of an ethnic-type gay and lesbian identity by those who have sex with members of the same gender (D'Emilio \& Freedman, 1997). Queer theory and queer politics have provided an alternative to the essentialist ideas sometimes adopted in LGBT politics. By adopting a deconstructionist approach, queer theory rejects fixed categories (e.g., "lesbians") and the idea that leaders of a movement can speak for its members. At its core, queer theory rejects notions of sexual identity and instead emphasizes the fluidity of human sexuality. Queer approaches are more open and inclusive, which can lead to opening discourse with others rather than shutting people off into ghettoized categories (Alexander, 1999; Gamson, 1995; Sedgwick, 1990). In some ways, queer approaches seem to be a new version of the early tactics of gay and lesbian activists, who were very assertive in building coalitions with other civil rights movements. However, while queer approaches seek to be inclusive, they also seek a radical disruption of norms that has sometimes resulted in a very specific group being at the center (e.g., white middle class men). This radical approach has resulted in producing another binary (i.e., straight versus queer) and has oftentimes resulted in the same ethnictype identity that "queerness" was supposed to eliminate (Cohen, 2005; Gamson, 1995; Smith, 1996).

Gamson (1995) explains that there is a "queer dilemma" that recognizes the validity and problems in the arguments of both the identity defenders and the queer supporters. On the one hand, LGBT boundaries are false and distorted. Although there is debate on whether sexual preference is innate, learned, chosen, or some combination, there are no firm distinctions between gay/lesbian, bisexual, transgender, and straight. Therefore, LGBT politics are sometimes problematic due to the presentation of LGBT issues as unified and shared among all people who identify as LGBT. Unification can result in a push toward conformity among group members (Alexander, 1999). For example, some LGBT individuals do not believe in marriage for anyone, while others seek to marry their same-sex partners. Another problem is seen through the specificity of LGBT issues. Small groups of LGBT individuals can only bring about small amounts of change without support from broader constituencies (see Cohen, 2005; Lee, Murphy, North, \& Ucelli, 2000). For example, the focus on domestic partner benefits is more appealing to other groups when it includes all couples and not just same-sex couples. The emphasis on marriage rights for same-sex couples is often used as an example of a cause that is of limited interest to those who do not currently identify as LGBT (e.g., "Beyond same-sex marriage: A new strategic vision for all our families and relationships," 2006).

On the other hand, a collective identity is necessary in our current context because "interest-group politics...is... how the American sociopolitical environment is structured" (Gamson, 1995, p. 400). Labels such as "gay," "black," and "Latino" are not merely constructions of language, they are social constructions that have tangible social consequences for people (Green, 2002). Among African Americans, there has been debate about expanding the small number of formal race categories and including broader multicultural categories. Although there is recognition that narrow conceptions of race are not accurate, narrow categorization is seen as the only way to fight discrimination, based on the current system structure. As Gamson (1995) points out, many members of the Right, along with queer theorists and activists, reject the idea of a fixed homosexual identity. The Right uses this argument to argue against legal protections based on sexual orientation, since sexuality cannot be easily categorized. They argue that since sexuality is fluid, it is difficult to discriminate based on a constantly changing sexual preference because we could all end up having sex with someone of the same gender.

There are obvious flaws and dangers in both identity-oriented approaches and queer approaches. However, there is a possibility for utilizing and recognizing both approaches (Gamson, 1995). Alexander (1999) contends that we cannot eliminate identity; however, he calls for an emphasis on shared values that we have in common among ourselves and with others. Through emphasizing these shared values, we open ourselves up to partnerships with broader groups and larger constituencies. He provides the Religious Right as an example of emphasizing shared values. Within the Religious Right, there are great differences on specific theological issues. Few religious sects agree on theology. However, members of the Religious Right have strategically underemphasized (but not ignored) their theological differences and have rallied around these shared values, which has resulted in an extraordinarily 
powerful movement. For LGBT ERGs, opportunities exist for emphasizing shared values with other groups. There are opportunities for joining forces with other groups on issues like domestic partner benefits for unmarried couples (not just for same-gender couples). Another possible area for joint advocacy is working to enhance benefits for working parents. Although members of LGBT ERGs must be cautious since they are often viewed as competing with or threatening to other groups (Creed \& Scully, 2000; Hirsch, 2000), this emphasis on shared values could create new opportunities for collaborative efforts to seek organizational changes.

Employee activists do more than advocate for large-scale policy changes like domestic partner benefits. Smallscale, local changes are often rejected as being insignificant; however, the day-to-day work of employee activism is largely centered around such changes (Scully \& Segal, 2002). In organizations, the most important decisions usually happen at the local level, which is where ERGs have great potential to make an impact. When asking members of ERGs what they have accomplished or what they actually do, Scully and Segal found that for many ERGs, merely existing was an accomplishment in itself. The support and visibility provided through the groups' existence was a significant social change. For LGBT groups, this queering of corporate spaces is a crucial activity. As more companies adopt equitable benefits packages and enact LGBT-friendly policies, groups will likely emphasize smaller-scale awareness and education efforts rather than sweeping changes. These smaller-scale efforts have the potential of using queer approaches that would upset the neat boundaries of sexuality. For example, in a building renovation project, an LGBT group could join with an employee group that advocates for individuals with disabilities to request a private, non-gendered restroom. This restroom could make life easier for a future transgender employee (if that individual was not comfortable using a larger restroom) and could also be beneficial for some people with disabilities who prefer more privacy and space.

To a certain degree, LGBT ERGs already balance queer approaches and identity-based approaches to political and social action. ERGs rely on identity-based approaches as an organizing tool. However, activism within corporations is necessarily more conservative than activism occurring through community-based groups. In fact, Raeburn (2004b) contends that some of the success of ERGs was a result of the contrasting images of professionalappearing employees seeking change from inside the company, when compared to queer activists outside the corporation. According to Raeburn's evidence, corporate executives were happy to deal with a calm and collected employee, when they considered the alternative. In these cases, the LGBT movement benefited from both the insiders and the outsiders (the "professionals" and the "queers"), whose work was complementary in many respects. However, many queer activists reject the work of ERGs as being assimilationalist since large corporations are a quintessential representation of power and privilege in modern society. The existence of LGBT groups within corporations is a major departure from the gay and lesbian movement of the 1960s, when overthrow of social institutions was a major goal (D'Emilio \& Freedman, 1997). Some LGBT activists are unhappy about this mainstreaming of the movement. However, representations of queerness within large, conservative organizations are somewhat jarring to the status quo. Thirty years ago, most LGBT people would not have considered being open about their sexuality at work. Today, many are open and some even organize meetings and events with others who are LGBT. This public display of sexuality has the effect of both queering the corporation and normalizing queerness. In the following section, I explore the problems and possibilities surrounding the normalization of queerness within corporations and the queering of corporations that result from LGBT ERGs.

\section{Normalization of Queerness}

The idea of normalizing queerness is undoubtedly troubling to many LGBT and queer activists. If queerness becomes normalized or mainstream, it essentially loses its meaning since the word "queer" describes the rejection of normativity. In order to consider the normalization of queerness through LGBT ERGs, it is helpful to consider advertising and the LGBT consumer market. Due to a desire for profits, advertisers and corporations have reached out to the LGBT audience. The use of queerness to market consumer products has been quite controversial for queers. However, lessons can be learned from the response to queer consumerism when considering LGBT ERGs since there are some parallels between the two developments. As I explained earlier, D'Emilio (1993) contends that capitalism has allowed for the emergence of a modern LGBT identity. In recent years, capitalist employment practices have allowed LGBT workers to assert themselves and seek changes in largely non-unionized workplaces.

The appropriation of queerness by business interests is welcome by some, due to the power of business to legitimize. However, others bemoan this legitimization by corporate interests due to their suspicion of capitalism and the fear of queerness being overtaken by corporate interests (Berlant \& Freeman, 1993). Specifically, queerness loses its radical edge when appropriated by corporations. For example, Alexander (1999) and Hill (1996) explain that the use of gays and lesbians in ads contributes to the assimilationist goal of showing that gays and lesbians are like everyone else. This is seen as undesirable because such ads usually contain a sanitized version of queerness that 
rarely includes those in the fringe. However, queerness is also seen through advertising. Numerous examples of the ambiguous use of gay and lesbian themes exist in mainstream advertising outlets. The use of androgynous models and subtly queer references in advertisements has resulted in a queering of mainstream spaces. Subtle examples abound in advertising, in which subtly gay, lesbian, or homoerotic images are the focus of the ad (e.g., Abercrombie and Fitch and J. Crew ads). Clark (1993) explains that we must be careful to not reject such ads immediately due to anti-corporate predispositions, which can result in giving too much power to corporations and seeing ourselves as powerless. Instead, she advocates D'Emilio's perspective of working through the interplay of autonomy and exploitation. The appropriation of queerness by corporations benefits those companies, but has the potential to benefit queers as well. With LGBT ERGs, we see members participating in pride parades and being featured in advertisements of LGBT publications. Additionally, employers promote ERGs both inside and outside their companies as evidence of their "commitment to diversity." Similar to the consumer marketing, it is valuable to recognize the problems with queerness being normalized and toned down in order for companies to promote their diversity. However, it is valuable to recognize that queers can also use companies for their benefit. It is not necessarily a case of exploitation by one group or the other, but rather a dynamic tension in which both queers and corporations are seeking benefits. Many of the benefits are complementary rather than opposing.

\section{Dangers and Promises of ERGs}

Foucault's (1978) notion of "bio-power" explains the self-regulation of individuals through social norms and values. In the past, government enforcement occurred through the constant threat of violence by governmental authorities. Today, the threat of government-sponsored violence is rarely necessary to "administer the bodies" of the masses. In the last few centuries, we have seen substantial growth of government institutions involved in the administration of bodies through agencies such as secondary schools, universities, and public health agencies. These institutions exercise bio-power, through inculcation of values that result in self-regulation, which has resulted in the comparatively rare use of physical violence by governments. Marshall (1995) expands on this concept by using the term "busno-power" to critically explore the commonly-held capitalist notion that people want free choice and autonomy in their lives. He contends that continuous free choices and individualized consumer decisions permeate all aspects of our lives. For example, as explained earlier, workers are now encouraged to seek out the employer that best meets their needs. Marshall problematizes such ideas by explaining that consumers must make endless free choices in all aspects of their lives and become mini economic enterprises themselves. Individuals must respond continuously to market demands and develop the skills necessary to survive, which results in a totalizing influence in individuals' lives. The ideas of busno-power can be extended further to explain the need of workers to seek individual meaning in their lives. Through a consumer mentality, workers seek meaningful work opportunities continuously in order to find the job that best suits their needs. Individuals, or mini economic enterprises, are not only responsible for their own fate, but also need to find personal fulfillment through work. Workers are responsible for selling their labor, in addition to confronting the newer expectation that they give up (or share) a part of their soul in order to meaningfully contribute to the corporation (Ciulla, 2000; Elliott \& Turnbull, 2003).

This overemphasis on individual needs through work can be dangerous due to its totalizing qualities. First, there is the constant threat of exploitation. If one's meaning is wrapped up in work, why not dedicate all of one's waking hours to work? When meaning and happiness is found through work, there is little need for limiting oneself to a 40-hour workweek. Second, it is possible that a corporation could become progressive on LGBT issues, but be less progressive or even oppressive on other issues (e.g., the use of sweatshops) (Truesdell, 2001). There is a danger that this limited focus on LGBT issues could result in a blindness to others' conditions (Duggan, 2003). Third, workers are laid off. With employers now providing leisure and spiritual activities within the confines of the corporate campus, many workers have no significant life outside of work. When workers lose their jobs, great depression and angst can result. Fourth, communities can suffer. When work serves as a main source of meaning, people have little need to meet neighbors, participate in civic organizations, or volunteer in the community.

ERGs and the activities of employee activists have the potential of being yet another example of total influence of the employer on the life of the worker. If substantial changes are made in workplaces, LGBT employees may become happier in their jobs, which could result in even more time spent at work. One could also argue that those who have activist instincts are no longer seeking change in society, but merely want to change the corporation. However, a less pessimistic viewpoint sees the promise that ERGs have for overcoming these dilemmas and contributing to the great public good. Mayo (2005) explains that busno-power is resisted through small everyday acts and Gibson-Graham (1996) explains that common activities often result in re-imagining capitalism. We often fail to see these new formations of capitalism because of a negative focus and blindness to new social formations. Participation in ERGs can be a location of resistance to the dominant focus on individual and corporate needs, which 
permeates workplaces. ERGs do not merely seek to meet individual or corporate needs, instead they can result in the re-imagining of workplaces that moves beyond the dominant focus on individualistic goals and corporate-profits. In fact, participation in activist-oriented ERGs is not likely to be the quickest means to advance one's career. Instead, ERGs include a societal and political dimension, which counters the depoliticized discourse commonly found in corporations (Elliott \& Turnbull, 2003). By focusing on a cause larger than one's immediate personal goals, workers can become more grounded in a larger sense of purpose beyond their own "mini economies." These activist activities could result in relationships and activism outside of the workplace realm. Therefore, ERGs can serve a larger purpose in helping people to resist the individualistic and careerist aims often seen in organizations. ERG members challenge corporate norms, which helps to counter the dominant unitary ideas expressed frequently by corporate leaders (e.g., "What's good for the company is good for the employee”) (see Ciulla, 2000; McGuire, Cross, \& O'Donnell, 2005). These processes create an opportunity for individuals to understand themselves, their friends, their corporations, and society in a different way.

\section{Conclusion}

Through ERGs, individuals can develop themselves by becoming more socially aware and working for a cause larger than oneself. ERGs provide organization development by helping companies become more humane and equitable places of employment. As a result, organizational performance can be enhanced as a result of improving workplace climate, employee relations, and public relations. ERGs can result in societal development by making societies more inclusive, less individualistic, and more community-oriented.

As I mentioned in the introduction, LGBT employee activists continuously balance their drive for social change and their need to contribute to organizational productivity. However, their role is not as simple as dealing with those two binaries. Additionally, employee activists deal with how much to utilize identity politics and queer approaches or how to imagine new strategies of social change. They also deal with how much to allow for an appropriation of gayness and queerness by the corporation. Lastly, these employees continuously juggle their individual needs as a worker-consumer, a worker-meaning seeker, a worker-activist, and the manager of a mini economy.

As stated earlier, a productive tension exists in which LGBT employees and corporations both seek benefits from ERGs. Some LGBT employees are self-interested and are only concerned with their own narrow concerns. Others want to contribute to the corporation and to improve conditions for both themselves and others. Likewise, some corporations are merely concerned with direct links to improved performance while other corporations seek to improve performance while striving to create a more equitable and humane workplace. All of these competing interests and goals result in a dynamic interplay that utilize capitalist structures and help to counteract the negative demands of capitalism through development and change at the individual, organizational, and societal levels.

\section{References}

Alexander, J. (1999). Beyond identity: Queer values and community. International Journal of Sexuality and Gender Studies, 4(4), 293-314.

Berlant, L., \& Freeman, E. (1993). Queer nationality. In M. Warner (Ed.), Fear of a queer planet: Queer politics and social theory (pp. 193-229). Minneapolis: University of Minnesota Press.

Beyond same-sex marriage: A new strategic vision for all our families and relationships. (2006, July 26, 2006). Retrieved December 3, 2006, from http://www.beyondmarriage.org/full_statement.html

Britzman, D. P. (1995). Is there a queer pedagogy? Or stop reading straight. Educational Theory, 45(2), $151-165$.

Ciulla, J. B. (2000). The working life: The promise and betrayal of modern work. New York: Times Books.

Clark, D. (1993). Commodity lesbianism. In H. Abelove, M. A. Barale \& D. M. Halperin (Eds.), The lesbian and gay studies reader (pp. 186-201). New York: Routledge.

Cohen, C. J. (2005). Punks, bulldaggers, and welfare queens: The radical potential of queer politics? In E. P. Johnson \& M. Henderson (Eds.), Black queer studies: A critical anthology (pp. 21-51). Durham, NC: Duke University Press.

Creed, W. E. D., \& Scully, M. A. (2000). Songs of ourselves: Employees' deployment of social identity in workplace encounters. Journal of Management Inquiry, 9(4), 391-412.

D'Emilio, J. (1993). Capitalism and gay identity. In H. Abelove, M. A. Barale \& D. M. Halperin (Eds.), The lesbian and gay studies reader (pp. 467-476). New York: Routledge.

D'Emilio, J., \& Freedman, E. B. (1997). Intimate matters: A history of sexuality in America (2nd ed.). Chicago: University of Chicago Press. 
Duggan, L. (2003). The twilight of equality? Neoliberalism, cultural politics, and the attack on democracy. Boston: Beacon Press.

Elliott, C., \& Turnbull, S. (2003). Reconciling autonomy and community: The paradoxical role of HRD. In M. Lee (Ed.), HRD in a complex world (pp. 100-116). London: Routledge.

Fenwick, T. J. (2005). Conceptions of critical HRD: Dilemmas for theory and practice. Human Resource Development International, 8(2), 225-238.

Foucault, M. (1978). The history of sexuality. New York: Pantheon Books.

Gamson, J. (1995). Must identity movements self-destruct? A queer dilemma. Social Problems, 42(3), 390-407.

Gedro, J. (2007). Conducting research on LGBT issues: Leading the field all over again! Human Resource Development Quarterly, 18(2), 153-158.

Gibson-Graham, J. K. (1996). Queer(y)ing capitalist organization. Organization, 3(4), 541-545.

Githens, R. P., \& Aragon, S. R. (2007). LGBTQ employee groups: Who are they good for? How are they organized? In L. Servage \& T. Fenwick (Eds.), Learning in Community: Proceedings of the Joint International Conference of the Adult Education Research Conference (AERC) (48th National Conference) and the Canadian Association for the Study of Adult Education (CASAE) (26th National Conference) (pp. 223-228). Edmonton: University of Alberta.

Green, A. I. (2002). Gay but not queer: Toward a post-queer study of sexuality. Theory and Society, 31(4), 521-545.

Hatcher, T. (2006). An editor's challenge to human resource development. Human Resource Development Quarterly, 17(1), 1-4.

Heyes, C. (2002). Identity politics. In E. N. Zalta (Ed.), The Stanford Encyclopedia of Philosophy (Fall 2002 ed.).

Hill, R. (1996). Learning to transgress: A socio-historical conspectus of the American gay life world as a site of struggle and resistance. Studies in the Education of Adults, 28(2), 253-279.

Hirsch, L. P. (2000). A wheel within a wheel: Sexual orientation and the federal workforce. In J. D'Emilio, W. B. Turner \& U. Vaid (Eds.), Creating change: Sexuality, public policy, and civil rights (pp. 129-146). New York: St. Martin's Press.

Human Rights Campaign Foundation. (2007). Workplace database. Retrieved September 1, 2007, from http://www.hrc.org/employersearch/

Lee, N. T., Murphy, D., North, L., \& Ucelli, J. (2000). Bridging race, class, and sexuality for school reform. In J. D'Emilio, W. B. Turner \& U. Vaid (Eds.), Creating change: Sexuality, public policy, and civil rights (pp. 251260). New York: St. Martin's Press.

Marshall, J. D. (1995). Foucault and neo-liberalism: Biopower and busno-power [Electronic Version]. Retrieved November 21, 2006 from http://www.ed.uiuc.edu/eps/PES-Yearbook/95_docs/marshall.html.

Mayo, C. (2005). Testing Resistance: Busno-cratic power, standardized tests, and care of the self. Educational Philosophy and Theory, 37(3), 357-363.

McGuire, D., Cross, C., \& O'Donnell, D. (2005). Why humanistic approaches in HRD won't work. Human Resource Development Quarterly, 16(1), 131-137.

National Gay and Lesbian Task Force. (2007). State nondiscrimination laws in the U.S. Retrieved August 15, 2007, from http://www.thetaskforce.org/downloads/reports/issue_maps/non_discrimination_07_07_color.pdf

O'Donnell, D. (2007). On critical theory in a truth-less world. Advances in Developing Human Resources, 9(1), 111119.

Raeburn, N. C. (2004a). Changing corporate America from inside out: Lesbian and gay workplace rights. Minneapolis: University of Minnesota Press.

Raeburn, N. C. (2004b). Working it out: The emergence and diffusion of the workplace movement for lesbian, gay, and bisexual rights. In D. J. Myers \& D. M. Cress (Eds.), Authority in contention (pp. 187-230). Amsterdam: Elsevier.

Robson, R. (1997). To market, to market: Considering class in the context of lesbian legal theories and reforms. In S. Raffo (Ed.), Queerly classed (pp. 165-178). Boston, MA: South End Press.

Scully, M., \& Segal, A. (2002). Passion with an umbrella: Grassroots activists in the workplace. In M. Lounsbury \& M. J. Ventresca (Eds.), Social structure and organizations revisited (Vol. 19, pp. 125-168). San Diego, CA: Elsevier Science.

Sedgwick, E. K. (1990). Epistemology of the closet. Berkeley: University of California Press.

Smith, S. (1996). From "Mistaken identity--or can identity politics liberate the oppressed?" In D. E. Morton (Ed.), The material queer: A LesBiGay cultural studies reader (pp. 337-343). Boulder, CO: Westview.

Truesdell, J. (2001). Kingdom come: Gay days at Disney World. In K. Krupat \& P. McCreery (Eds.), Out at work: Building a gay-labor alliance (pp. 211-231). Minneapolis: University of Minnesota Press.

Yoshino, K. (2006). Covering: The hidden assault on our civil rights. New York: Random House. 